\title{
Prediction of Bridge Pier Scour Depth and Field Scour Depth Monitoring
}

\author{
Fong-Zuo Lee ${ }^{1}$, Jihn-Sung Lai ${ }^{1}$, Yuan-Bin $\mathrm{Lin}^{2}$, Kuo-Chun Chang ${ }^{3}$, Xiaoqin $\mathrm{Liu}^{2}$, and \\ Cheng-Chia Huang ${ }^{1}$ \\ ${ }^{1}$ Hydrotech Research Institute, National Taiwan University, Taipei 10617, Taiwan (R.O.C.) \\ ${ }^{2}$ National Center for Research on Earthquake Engineering, National Applied Research Laboratories, \\ Taipei 10617, Taiwan (R.O.C.) \\ ${ }^{3}$ Department of Civil Engineering, National Taiwan University, Taipei 10617, Taiwan (R.O.C.)
}

\begin{abstract}
In practice, it is a major challenge in real-time simulation and prediction of bridge pier scour depth, especially using 3-D numerical model. The simulation time spend too much to use 3-D numerical model simulation and inefficiently to predict bridge pier scour depth in real-time. With heavy rainfall during flood season in Taiwan, abundant sediment with flash flood from upstream watershed is transported to downstream river reaches and transportation time is limited within one day. The flood flow tends to damage bridge structures and affect channel stabilization in fluvial rivers. In addition, the main factors affecting the erosional depth around bridge piers and river bed stabilization are hydrological and hydrographic characteristics in river basin, the scouring and silting of river bed section near the bridge piers, the bridge geometry and protection works of bridge piers. Therefore, based on the observed rainfall data provided by the Central Weather Bureau and the hydrological conditions provided by the Water Resources Agency during flood event as the boundary condition, we develop an effective simulation system for scour depth of bridge piers. The scour depth at the bridge pier is observed by the National Center for Research on Earthquake Engineering for model calibration. In this study, an innovative scour monitoring system using vibration-based Micro-Electro Mechanical Systems (MEMS) sensors was applied. This vibration-based MEMS sensor was packaged inside a stainless sphere with the proper protection of the fullfilled resin, which can measure free vibration signals to detect scouring/deposition processes at the bridge pier. It has demonstrated that the measurement system for monitoring bridge scour depth evolution is quite successful in the field.
\end{abstract}

\section{Introduction}

With heavy rainfall during flood season in Taiwan, abundant sediment with flash flood from upstream watershed is transported to downstream river reaches and transportation time is limited within one day. The flood flow tends to damage bridge structures and affect channel stabilization in fluvial rivers. In addition, the main factors affecting the erosional depth around bridge piers and river bed stabilization are hydrological and hydrographic 
characteristics in river basin, the scouring and silting of river bed section near the bridge piers, the bridge geometry and protection works of bridge piers. Therefore, bridge scour occurs in fourth main forms, namely, general scour, contraction scour, bend scour and local scour (Prendergast and Gavin, 2014). In general, the general scour, contraction scour and local scour are the main courses of bridge scour. The general scour occurs naturally in river channels and includes the aggradation and degradation of the river bed. The general scour occurs as a result of changes from the hydraulic parameters of flow rate and sediment quantity in the channel (Forde et al., 1999). It relates to the evolution of the flow field and associates with the progression of scour and refilling around absence of obstacles (Federico et al., 2003). Contraction scour occurs as a result of the reduction in the channel's cross-sectional area that arises due to the construction of bridge piers and abutments. The contraction of crosssectional area induces an increase in flow velocity and results an increase in river bed shear stresses. This condition caused by a reduction in the channel's cross-sectional area at the location of a bridge. The increasing shear stresses can overcome the channel bed's threshold shear stress and mobilize the sediments in river channels (Briaud et al., 1999). Local scour occurs around individual bridge piers and abutments. Downward flow is induced at the upstream end of bridge piers, leading to much localized erosion in the direct vicinity of the structure (Hamill, 1999) (see Fig. 1). Horseshoe vortices occur owing to the separation of the flow at the edge of the scour hole upstream of the pier and result in forcing the down-flow inside the scour hole closer to the pier. Horseshoe vortices are a main result of initial scouring. Furthermore, separation of the flow at the sides and back of the bridge pier results in wake vortices and occurs the scour as horseshoe shape (Heidarpour et al., 2010). Comparison of the general scour, contraction scour and local scour, the local scour is the main reason to result in most part of bridge scour. The hydraulic parameters of local scour includes the diameter of bridge piers, incoming flow depth and flow velocity and grain sizes. Therefore, how to measure or simulate the flow depth and flow velocity are the main keys and challenges in the field.

In this study, based on the observed rainfall data and the rainfall runoff routing, we develop a simulation system with empirical formulas for scour depth of bridge piers and compare to an innovative monitoring results.

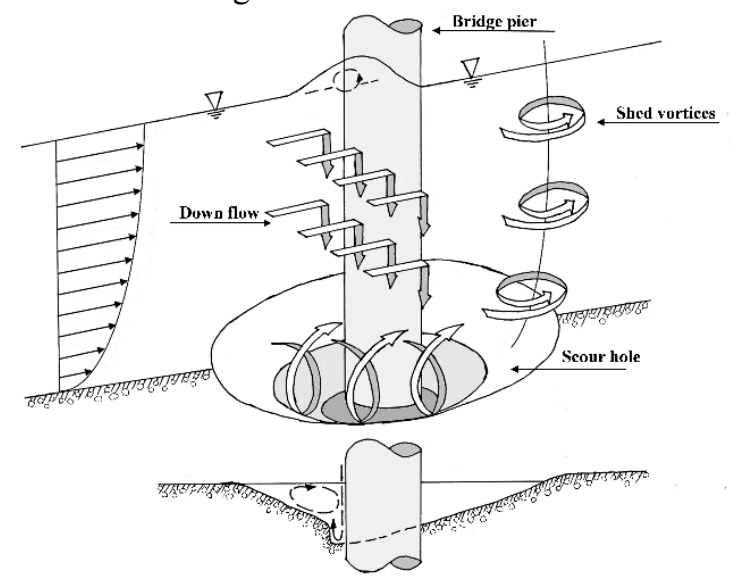

Fig. 1. Schematic of scour mechanism and flow pattern.

\section{Study area}

Prediction of bridge pier scour depth and field scour depth monitoring was conducted at the Mingchu Bridge which is in the middle Cho-Shui River, the longest river in Taiwan as shown 
in Fig. 2. (a). The watershed above the Mingchu Bridge is about $2105 \mathrm{~km}^{2}$. The Chi-Chi weir is located approximately $6.5 \mathrm{~km}$ upstream of the Mingchu Bridge and is the upstream boundary location of this study. Because of no tributary flows between the weir and the bridge, the flow discharge measured at the Chi-Chi Weir is nearly the same as the flow at the bridge. However, the downstream river reach has two tributaries flow into the main river. Therefore, the tributary discharge are given from the field measurement data at Yanping and Longmen bridges. The downstream boundary condition of water level is set at Tai No.61 Western Coast Expressway. The median size of bed material around Mingchu Bridge, $\mathrm{d}_{50}$, was about $62 \mathrm{~mm}$, indicating a highly non-uniform gradation (National Center for Research on Earthquake Engineering, 2012). The Mingchu Bridge is situated in the flood channel and it consists of 13 spans and 12 cylindrical columns ( $2.8 \mathrm{~m}$ in diameter). Each column rests on a piled foundation (12 m cap width) buried below the streambed (Hong et al., 2014).

In addition, the character of monitoring system should possess high durability and high sensitivity property. To take requisite precautions against such catastrophic conditions, a monitoring system that can reliably detect scour formation, without being adversely affected by the environmental conditions, is essential (Fisher et al., 2013). Since 2016 (Lai et al., 2017), applications of flood disaster monitoring technology and early warning simulation in Cho-Shui River basin is started to investigate. The monitoring sensor of bridge pier scour and numerical model are implemented to study the prediction of bridge pier scour depth. As a result, in this study, the development principle is that a Micro-Electro-Mechanical System (MEMS)-based vibration sensor by the turbulent flow vibrates at significantly higher amplitudes surrounded by bridge piers up and down the river bed (Lee et al., 2014, 2017). The sensor setup located at the P4 bridge pier of Mingchu Bridge and setup depth ranged from river bed to the elevation level (EL.) $143 \mathrm{~m}$, the deepest monitoring depth is constrained at EL. 143m (as shown in Fig. 2. (b)).

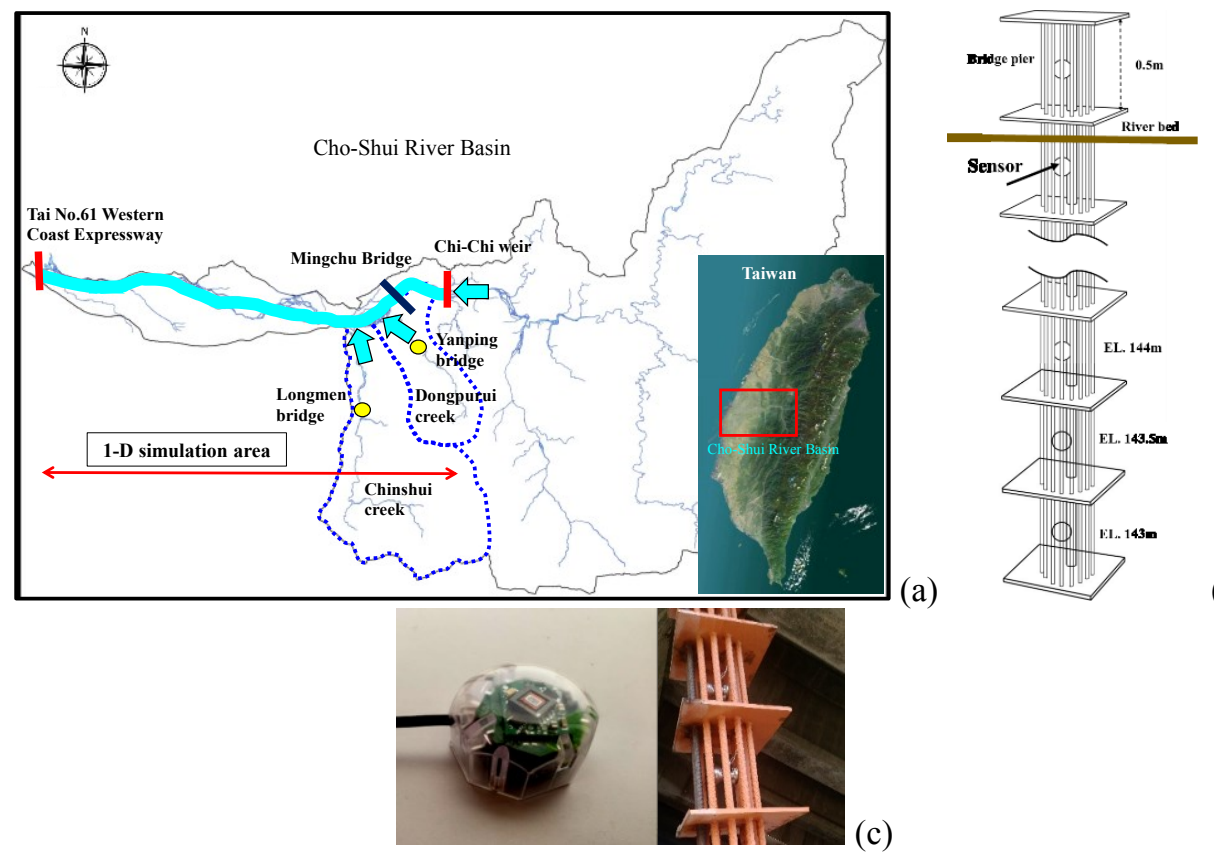

(b)

Fig. 2. Study area and locations (a) Cho-Shui River basin (b) sensors at Mingchu Bridge P4 pier(c) MEMS. 


\section{Methods}

Based on the observed rainfall data during flood event and the flood discharge forecast in river basin, we develop an effective simulation system for bridge pier scour depth. It consists of hydraulic model, general scour estimation, local scour estimation and contraction scour estimation. The details are described as following:

\subsection{Hydraulic model}

Most open-channel flows considering hydraulic scour depths are assumed shallow water and the effect of vertical flow motions are not calculated if the down flow along the bridge pier is implicated in hydraulic scour equations. In addition, for real time simulation and prediction, the simulation time is the main concerned factor. As a result, the 3D Navier-Stokes equations may be vertically averaged to obtain a set of depth-averaged and unit width 1-D equation to calculate water depth and flow velocity. The Sedimentation and River Hydraulics-1D (SRH1D) model is developed for studying open-channel flows with sediment transportation. The model is used for solving the 1-D shallow-water flow equation. The model can simulate the sub/supercritical flow and steady/unsteady flows in rivers that are generated by hydraulic structures such as bridge piers. Moreover, the model has been tested in several experimental or field cases in shallow-water flows, which has demonstrated that the model is suitable for practical applications in hydraulic engineering. SRH-1D uses the standard step method to solve the energy equation for steady gradually varied flows. Presently, only subcritical and critical flow profiles are calculated when the steady flow option is used. The energy equation for steady gradually varied flow between downstream cross section 1 and upstream cross section 2 is expressed as:

$$
Z_{2}+\beta_{2} \frac{V_{2}^{2}}{2 g}-Z_{1}-\beta_{1} \frac{V_{1}^{2}}{2 g}=h_{f}+h_{c}
$$

In which, $Z_{1}$ and $Z_{2}$ are water surface elevations at cross sections 1 and 2, respectively, $V_{1}$. and $V_{2}$ are the average velocities at cross sections 1 and 2 , respectively, $\beta_{1}$ and $\beta_{2}$ are velocity distribution coefficients at cross sections 1 and 2 , respectively, $\mathrm{g}$ is gravitational acceleration, $\mathrm{h}_{\mathrm{f}}$ is friction loss between cross sections 1 and $2, \mathrm{~h}_{\mathrm{e}}$ is contraction or expansion losses between cross sections 1 and 2 .

\subsection{General scour estimation}

There are two types of sediment routing available in SRH-1D (Jianchun and Blair, 2007) which are unsteady sediment routing and Exner equation routing. The unsteady sediment routing computes the changes to the suspended sediment concentration with time. The Exner equation routing ignores changes to the suspended sediment concentration over time. Unsteady sediment routing can be used when unsteady flow is being simulated and suspended concentrations change rapidly.

When simulating unsteady flow or sediment transport, the changes in suspended concentration with time may be important. To compute the changes in suspended sediment concentration, the convection-diffusion equation with a source term for sediment erosion/deposition is used. The $1 \mathrm{D}$ depth-averaged convection-diffusion equation for a particular sediment size class is:

$$
\frac{\partial A c}{\partial t}+\frac{\partial \xi Q c}{\partial x}=\frac{\partial}{\partial x}\left(f D_{x} A \frac{\partial c}{\partial x}\right)+\Omega,
$$


where $\mathrm{c}$ is depth averaged concentration, $\mathrm{A}$ is cross section area, $\mathrm{Q}$ is the flow rate, $\mathrm{f}$ is the fraction of suspended load, $\mathrm{D}_{\mathrm{x}}$ is diffusion coefficients streamwise directions, The parameter, $\xi$, is the velocity of sediment relative to the water. Finally, $\Omega$ is the source (erosion) and sink (deposition) terms for one sediment constituent.

\subsection{Local scour estimation}

The local scour depth evolution at the pier nose under unsteady flow is computed by a specific position proposed by Froehlich (1991) formula, Shen et al. (1966) formula, Neill (1964) formula, Inglis (1949) formula and Jain and Fischer (1980) formula in this study. The selected five different empirical equations are described as following:

$$
\begin{array}{cc}
\mathrm{Y}_{\mathrm{s}}=0.32 \varnothing \mathrm{b}^{0.62} \mathrm{Y}_{1}^{0.47} \mathrm{~F}_{\mathrm{r}}^{0.22} \mathrm{~d}_{50}^{-0.09} & (\text { Froehlich, 1991) } \\
\mathrm{Y}_{\mathrm{s}}=2.5 \mathrm{Y}_{1} \mathrm{~F}_{\mathrm{r}}^{2 / 3}\left(\mathrm{D} / \mathrm{Y}_{1}\right)^{0.6} & \text { (Shen et al. , 1966) } \\
\mathrm{Y}_{\mathrm{s}}=1.5 \mathrm{D}\left(\mathrm{Y}_{1} / \mathrm{D}\right)^{0.3} & \text { (Neill, 1964) } \\
\mathrm{Y}_{\mathrm{s}}=4.2 \mathrm{DF} \mathrm{F}_{\mathrm{r}}^{0.52}\left(\mathrm{Y}_{1} / \mathrm{b}\right)^{0.73} & \text { (Inglis, 1949) } \\
\mathrm{Y}_{\mathrm{s}}=1.86 \mathrm{D}\left(\mathrm{Y}_{1} / \mathrm{D}\right)^{0.5}\left(\mathrm{~F}_{\mathrm{r}}-\mathrm{F}_{\mathrm{rc}}\right)^{0.25} & (\text { Jain and Fischer, 1980) }
\end{array}
$$

In which, $\mathrm{Y}_{\mathrm{s}}$ is local scour depth, $\phi$ is correction coefficient of bridge noise shape, $\mathrm{b}$ is pier width of transverse to the flow direction, $Y_{1}$ is water depth of bridge upstream reach. $F_{r}$ is the Froude number of bridge upstream reach, $\mathrm{F}_{\mathrm{rc}}$ is critical Froude number of bridge upstream reach, $d_{50}$ is mean diameter of sediment size and $D$ is bridge pier width.

\subsection{Contraction scour estimation}

The contraction scour depth evolution at the pier nose under unsteady flow is computed by a specific position proposed by Laursen (1958). The hydraulic patterns around bridge piers that calculated by SRH-1D are applied to estimate the contraction scour depth. The adapted contraction scour depth formula is described as following:

$$
Y_{c}=Y_{1}\left[\left(\frac{Q_{2}}{Q_{1}}\right)^{7 / 6} \times\left(\frac{B_{1}}{B_{2}}\right)^{k_{1}} \times\left(\frac{n_{2}}{n_{1}}\right)^{k_{2}}-1\right]
$$

In which, $Y_{c}$ is contraction scour depth $(\mathrm{m}), Q_{1}$ is incoming discharge $\left(\mathrm{m}^{3} / \mathrm{s}\right), Q_{2}$ is discharge between bridge piers $\left(\mathrm{m}^{3} / \mathrm{s}\right), \mathrm{B}_{1}$ is the width of water surface $(\mathrm{m}), \mathrm{B}_{2}$ is the width between bridge piers $(\mathrm{m}), n_{1}$ is Manning coefficient of upstream river reach, $n_{2}$ is Manning coefficient of bridge pier reach, $\mathrm{k}_{1}$ and $\mathrm{k}_{2}$ are the ratio of shear velocity and fall velocity.

\section{Results and discussions}

For model calibration and verification, the scour depth at the bridge pier is observed by the National Center for Research on Earthquake Engineering. In this study, an innovative scour monitoring system using vibration-based Micro-Electro Mechanical Systems (MEMS) sensors were applied. Figure 3 and 4 show the results of bridge pier scour depth by field monitoring data at the Mingchu Bridge during Typhoon NEPARTAK and Typhon MEGI in 2016. The boundary conditions are listed in Fig. 3 and Fig. 4. It seems that the depth of bridge pier scour is accompanied with hydrological patterns. The circle symbol presents the hydrograph of field scour depth monitoring data and it consists of the scour and deposition process during typhoon events. Due to the monitoring system development of bridge pier scour depth is from river bed to the EL. $143 \mathrm{~m}$, the deepest monitoring depth is constrained at EL. $143 \mathrm{~m}$. So, we do not measure the deepest bridge scour depth during these two typhoon 
events. Based on the field monitoring data, the total scour depth is about $0.5 \mathrm{~m}$ in both two typhoon events. In addition, the vertical distance of sensors is $0.5 \mathrm{~m}$. It means that the performance of measured scour and deposition interval is also $0.5 \mathrm{~m}$. According to the monitoring data, the scour and deposition processes seems to follow the discharge hydrograph and the scour rate is higher than the deposition rate. However, the scour duration is shorter than the deposition duration. It means that reaction time of management office for the bridge safety is limited during bridge scour process. So, if the warning system of bridge safety is based on field monitoring system, the reaction time is very limited. Therefore, we develop a 1-D numerical model with empirical equations to predict the bridge scour depth for real time simulation in this study. The adapted rainfall data in the watershed is provided by the Central Weather Bureau and hydrological conditions are provided by Water Resources Agency. We also applied the Semi-distributed Parallel-type Linear Reservoir Runoff Model (Hsieh, 1999) for the inflow discharge as the boundary condition. The tributary discharge are given from the field measurement data at Yanping and Longmen bridges. The downstream boundary condition of water level is set at Tai No.61 Western Coast Expressway. The Figure 3 and 4 show the simulation results of numerical model with empirical equations for two typhoon events. Based on the simulation results, Shen et al. (1966) is over estimated on the bridge pier scour depth and Forehlich (1991) is lower estimated on the bridge pier scour depth. Inglis(1949) and Jain and Fisher(1980) are relatively agree with the maximum scour depth estimation. However, the mechanism of deposition process cannot be simulated well by all equations. 

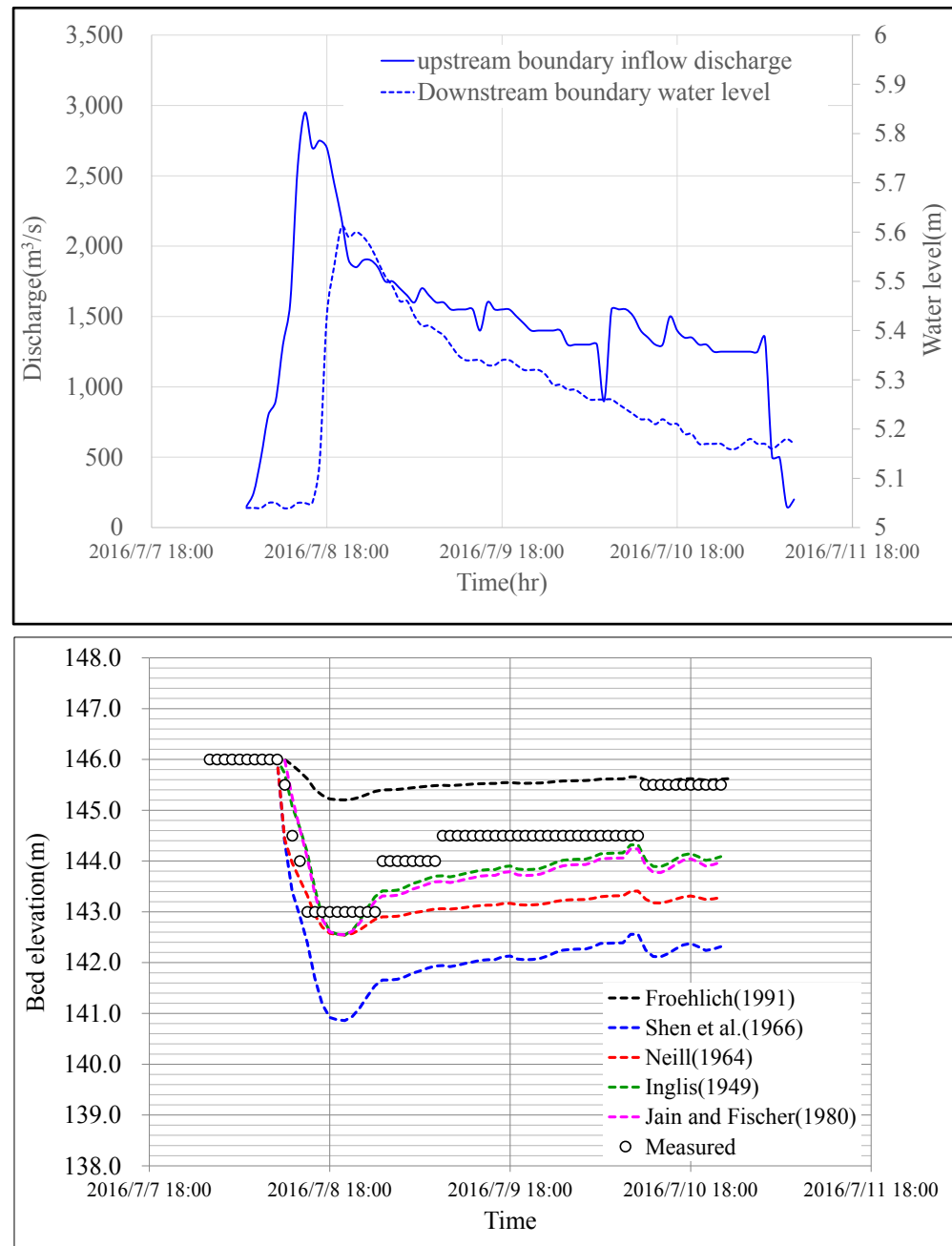

(a)

(b)

Fig. 3. Typhoon NEPARTAK in 2016 (a) boundary conditions (b) bridge pier scour depth. 

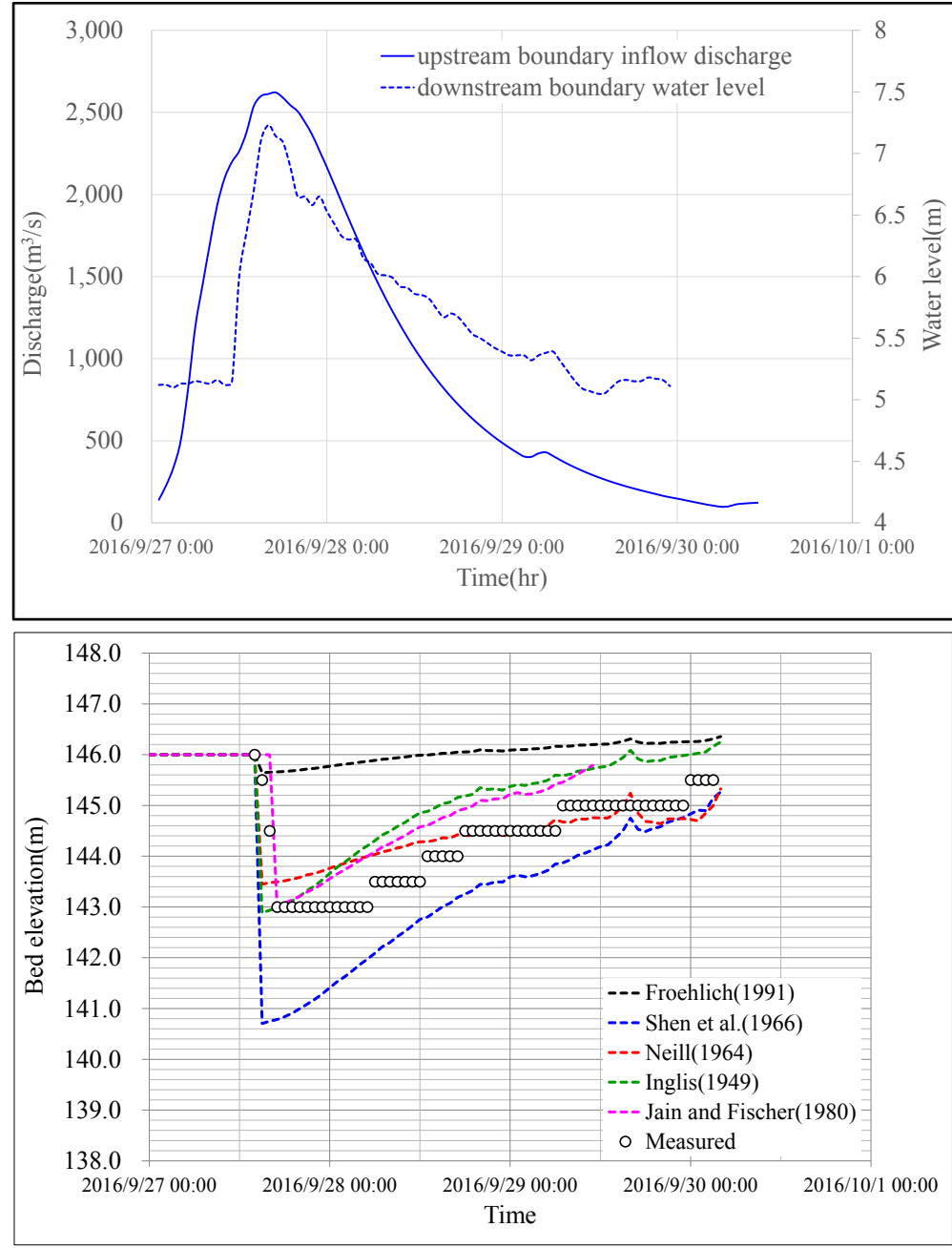

(a)

Fig. 4. Typhoon MEGI in 2016 (a) boundary conditions (b) bridge pier scour depth.

\section{Conclusions}

Based on the field survey data of hydrological condition and bridge pier scour depth measurement, we apply SRH-1D model combined with the formulas of local scour depth and contraction scour depth to calibrate and verify the parameters. The results show that the innovative scour monitoring system using vibration-based Micro-Electro Mechanical Systems (MEMS) sensors can present the depth sequence of scouring and deposition around bridge pier during typhoon induced flood event. In addition, the adapted numerical model and formulas can appropriately simulate the variation of bridge pier scour depth. Therefore, the prediction module of bridge pier scour depth and the system of field scour depth monitoring are developed. For practice, based on the rainfall prediction before flood event and the flood forecast in river basin, we can have an effective prediction system for scour depth of bridge piers in the future. Besides, the MEMS technology can provide real time bridge pier scour depth and could be helpful for the assessment of bridge safety. 


\section{Acknowledgement}

The presented study was supported by the Ministry of Science and Technology in Taiwan. Project number is MOST 106-3011-F-002-003. Writers wish to thank the National Taiwan University, U.S. Bureau of Reclamation and Taiwan Typhoon and Flood Research Institute for manpower and technique supporting. We also thanks the Central Weather Bureau and the Water Resources Agency for providing the rainfall data and hydrological conditions.

\section{References}

1. C.R. Neill, River bed Scour, a review for bridge engineers. Contract No. 281, Res. Council of Alberta, Calgary, Alberta, Canada (1964).

2. D.C. Froehlich, Analysis of Onsite Measurements of Scour at Piers. Proc., A.S.C.E., National Hydraulic Engineering Conference, Colorado Springs, CO (1991).

3. F. Federico, G. Silvagni, F. Volpi, Scour vulnerability of river bridge piers. Journal of Geotechnical and Geoenvironmental Engineering, 129(10). pp. 890-899 (2003).

4. F. Z. Lee, C. C. Huang, Y. J. Liao, W. Y. Chang, H. K. Chang, Y. C. Tan, Deviation of local scour and contraction scour near bridge with various scour formulas around bridge piers, Sixth World Conference on Structural Control and Monitoring, 6WCSCM, Barcelona, Spain (2014).

5. F.Z Lee, T.H. Huang, J.S. Lai, Y.B. Lin, K.C. Chang, Using 2-D Numerical Model Simulation on Bridge Scouring, Journal of Taiwan Agricultural Engineering, Vol. 63, No. 4, pp. 65-78 (2017). (In Chinese).

6. H.W. Shen, V.R. Schneider, S.S. Karaki, Mechanism of local Scour. Engineering Research Center, Colorado State Univ. Fort Collins, Colorado CER 66HWS22 (1966).

7. J.H. Hong, W.D. Guo, H.W. Wang, F.Z. Lee, Y.B. Lin, Field measurement and simulation of riverbed and bridge scour in Cho-Shui River in Taiwan. Sixth World Conference on Structural Control and Monitoring, 6WCSCM, Barcelona, Spain (2014).

8. J.L. Briaud, F. Ting, H.C. Chen, R. Gudavalli, S. Perugu, G. Wei, SRICOS: prediction of scour rate in cohesive soils at bridge piers. Journal of Geotechnical and Geoenvironmental Engineering, 125(4), pp. 237-246 (1999).

9. J.S. Lai, Applications of flood disaster monitoring and early warning technology in a river basin, Project No. MOST 106-3011-F-002-003 (2017).

10. L. Hamill, Bridge hydraulics. London: E\& FN Spon (1999).

11. L.J. Prendergast, K. Gavin, A review of bridge scour monitoring techniques. Journal of Rock Mechanics and Geotechnical Engineering, 6(2), pp. 138-149 (2014).

12. L.S. Hsieh, R.Y. Wang, A Semi-Distributed Parallel-Type Linear Reservoir RainfallRunoff Model and Its Application in Taiwan. Journal of Hydrological Processes, 13(8), pp.1247-1268 (1999).

13. M. Fisher, M.N. Chowdhury, A.A. Khan, S. Atamturktur, An evaluation of scour measurement devices. Flow Measurement and Instrumentation, 33(5), pp. $55-67$ (2013).

14. M. Heidarpour, H. Afzalimehr, E. Izadinia, Reduction of local scour around bridge pier groups using collars. International Journal of Sediment Research, 25(4), pp. 411-422 (2010).

15. M.C. Forde, D.M. McCann, M.R. Clark, K.J. Broughton, P.J. Fenning, A. Brown, Radar measurement of bridge scour. NDT\&E International, 32(8), pp. 481-492 (1999). 
16. National Center for Research on Earthquake Engineering, Flushing test and hydraulic measurement of bridge piers, National Taiwan University (2012). (In Chinese).

17. S.C. Inglis, Maximum depth of scour at heads of guide bands and groynes, pier noses, and downstream bridges-the behavior and control of rivers and canals. Indian Waterways Experimental Station, Poona, India (1949).

18. S.C. Jain, E.E. Fischer, Scour around Bridge Piers at High Velocity. Journal of Hydraulic Engineering, ASCE, 106(11), pp. 1827-1842 (1980).

19. SRH-1D, User's Manual, version 2.2, U.S. Department of the Interior, Bureau of Reclamation, Technical Service Center (2009).

20. V.H. Jianchun, G. Blair, User's Manual for SRH-1D V2.1 (2007). 